九州大学学術情報リポジトリ

Kyushu University Institutional Repository

Integrating $\mathrm{Climate}$ Change and other

Sustainable Development Goals in Cities: Making the Connections

Zusman, Eric

Institute for Global Environmental Strategies (IGES) : Research Leader

https://doi.org/10.5109/4738546

出版情報 : Proceedings of International Exchange and Innovation Conference on Engineering \& Sciences (IEICES). 7, pp. 28-29，2021-10-21. 九州大学大学院総合理工学府 バージョン:

権利関係 : 


\section{Keynote Speaker}

\section{Eric Zusman}

Research Leader

Institute for Global Environmental Strategies (IGES)

Email: zusman@iges.or.jp

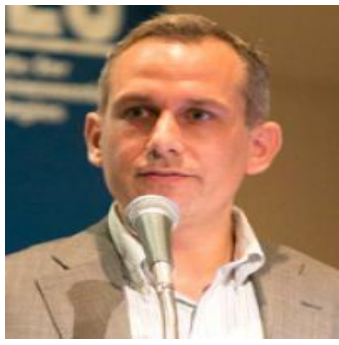

\section{Short Biography}

Eric Zusman is a senior policy researcher/area leader at the Institute for Global Environmental Studies in Hayama, Japan. Dr. Zusman holds a Bachelor's Degree in Mandarin Chinese from Rutgers University, a dual Master's Degree in public policy and Asian studies from the University of Texas at Austin and a Ph.D. in political science from the University of California, Los Angeles. For much of the past two decades he has conducted research on environmental issues in Asia. This has included working with China's Yellow River Conservancy Commission, the Chinese Research Academy on Environmental Science, Woodrow Wilson Center's China Environment Forum as well as Taiwan's Academia Sinica. He has published books and articles on water scarcity, air pollution regulation, environmental law, multilevel governance, sustainability transitions, low carbon development and the Sustainable Development Goals. He is currently serving as a lead author for the sixth assessment report of the Intergovernmental Panel on Climate Change (Chapter 17). 


\title{
Integrating Climate Change and other Sustainable Development Goals in Cities: Making the Connections
}

\begin{abstract}
The climate emergency is one of the greatest challenges facing humanity today. How effectively the international community responds to that challenge increasingly falls to cities. This is partially because cities consume over two-thirds of the world's energy and emit more than $70 \%$ of global CO2. It is also because fast rising GHG emissions have made cities ever more susceptible to heat waves, flooding, intense storms, and a litany of other adverse climate impacts. Fortunately, many cities have sought to limit their contributions and vulnerabilities to climate change. Often more flexible than national governments, many cities have capitalized on their agility to introduce innovative solutions to climate change at an impressive pace and scale. Yet, while a number of cities have moved quickly and confidently on climate change, not all have been convinced of the necessity of early or bold action. Moreover, even local authorities persuaded of the merits of taking such actions may have a scope to do more. A critical and often missing link in a cities' decision-making calculus is an understanding of how mitigating or adapting to climate change contributes to broader socioeconomic development objectives like those under the Sustainable Development Goals. This presentation will draw upon recent research to understand how cities are forging links between climate and wider development goals to accelerate and strengthen action on the greatest challenge facing humanity today.
\end{abstract}

